KRAUSZ Bernadett

DOI: 10.15170/DIKE.2021.05.01.09

PhD-hallgató

PTE ÁJK

bírósági fogalmazó

Nagykanizsai Járásbíróság

\title{
A házasságon kívül született gyermek jogállása különös tekintettel a tartásdíj kiszabásának bírói gyakorlatára 1945 és 1950 között Magyarországon
}

\section{The Legal Status of Illegitimate Children, with Special Regard to the Judicial Practice of Imposing Maintenance in Hungary between 1945 and 1950}

There was a legal differentiation between children born in and out of wedlock in 1945. The Hungarian State recognised that this differentiation was outdated, thus the Act XXIX of 1946 on the legal status of children born out of wedlock came into force on June 7, 1947. The aims of the Act were that it should cease the differentiation between children born in and out of wedlock and their legal status shall be equal to legitimate children, and the children born out of wedlock (illegitimate children) shall be related to their fathers and their fathers' kin. It was the first comprehensive regulation regarding child support that came into effect. The study presents the regulations of child support between 1945 and 1950 in Hungary and discloses the court practice regarding child support of the District Court of Zalaegerszeg in the designated period.

Keywords: family law, maintenance, minor, judicial practice, illegitimate children, judicial practice

\section{Bevezető gondolatok}

A házasságon kívül született, az ún. „törvénytelen” vagy „természetes” gyermekek jogi helyzete különbözött a törvényes házasságból született gyermekekétől az 1946. december 19. napján kihirdetett, a házasságon kívül született gyermek jogállásáról szóló 1946. évi XXIX. törvénycikk hatálybalépéséig (1947. június $7 .^{1}$ ), amely megszüntette ezt a különbségtételt. ${ }^{2}$ Igaz, hogy a Tanácsköztársaság ideje alatt is voltak ezirányú törekvések, ugyanis a Forradalmi Kormányzótanács 1919. március 26. napján megjelent VII. sz. rendeletének 1. S szerint a Magyarországi Tanácsköztársaság törvénytelen gyermeket nem ismer. Mindazok a jogok és kötelezettségek, amelyek a törvényes házasságból született gyermeket megilletik (pl. névviselés, tartás, családi pótlék

\footnotetext{
1 MiKOS - ZAJTAY - SÁRFFY, A polgári eljárásjog 64.

2 1946. évi XXIX. törvénycikk 1. 』 A jelen törvény célja az, hogy az emberi egyenlőség eszméjének szolgálatában a családi jogállás egyenlőségét is a származástól függetlenül az élet minden vonatkozásában minél teljesebben érvényesítse. Ehhez képest a jelen törvény erejénél fogva a törvényes és törvénytelen származás megkülönböztetése megszűnik.
} 
stb.) csorbítatlanul kiterjednek azokra a gyermekekre is, akik házasságon kívül születtek, ${ }^{3}$ azonban a kommün bukásával ez a rendelet is hatályát vesztette.

Az 1946. évi XXIX. törvénycikk a jogi különbségtétel megszüntetése mellett a házassági köteléki jogon kívül átfogóan, tételes jogi normákkal szabályozta azokat a családjogi intézményeket a házasságon kívül született gyermekek vonatkozásában, amelyekről azelőtt csak különálló törvények rendelkeztek legfeljebb néhány szakaszban ${ }^{4}$ vagy egyáltalán nem. ${ }^{5}$ Ezek a fogantatási idő vélelme, az apai elismerés, az apaság megállapítása, a gyermekelhelyezés és a szülői hatalom, a gyermektartásdij, valamint a gyermek névviselése és az ezekhez kapcsolódó eljárásjogi szabályok voltak.

A tanulmányban a jogszabály gyermektartásdíjra vonatkozó szabályozásának ismertetése után a Zala megyei bírói gyakorlat kerül bemutatásra. Tekintettel arra, hogy gyermektartásdíj megfizetése iránt indított perek a járásbíróságok hatáskörébe tartoztak ${ }^{6}$, illetve, hogy a Magyar Nemzeti Levéltár Zala Megyei Levéltárának vonatkozó iratai közül a legnagyobb mértékben a zalaegerszegi iratok maradtak fenn, így a Zalaegerszegi Járásbíróság iratait vizsgáltam meg.

\section{A jogi kihívások és a gyermektartásdíj vitás kérdéskörei}

Az 1946. évi XXIX. törvénycikk jelentőségének megértéséhez szükséges annak megismerése, hogy 1945-ben milyen volt a házasságon kívül született gyermekek jogállása, és melyek voltak azok a kérdéskörök a gyermektartásdíj vonatkozásában, amelyek komoly vitákat generáltak a szakirodalomban az eltérô bírói gyakorlatra tekintettel.

A házasságon kívül született gyermek jogilag csak az anyjával és az anya rokonaival állt rokoni kapcsolatban, így öröklési joga csak ezen személyi körben volt. Az apával rokoni kapcsolatban nem állt, ôt csupán tartási kötelezettség terhelte a gyermekkel szemben, amennyiben a járásbíróság megállapította, hogy a gyermek anyja és a perbevont férfi a fogantatási időben nemileg érintkeztek. ${ }^{7}$ A gyermektartásdíj megállapítása iránt indított peres eljárásban a bizonyítás sok esetben nehéz volt, mivel a felek tényállitásain ${ }^{8}$ kívül a felek eskü alatti kihallgatása során tett nyilatkozatok, ${ }^{9}$ tanúvallomások ${ }^{10}$ és okiratok ${ }^{11}$ (pl. felek közötti esetleges levelek) is bizonyítékként

\footnotetext{
${ }^{3}$ KÖTE - RAVASZ, Dokumentumok a magyar nevelés történetéből 506.

${ }^{4}$ Az 1946. évi XXIX. törvénycikk hatálybalépése előtt az abban foglalt intézményekről rendelkezett - a teljesség igénye nélkül - a gyámsági és gondnoksági ügyek rendezéséről szóló 1877. évi XX. törvénycikk (Gyt.) 11. \a gyermektartásról, a 13. \a gyermekelhelyezésről, a II. fejezet az atyai hatalomról; a házassági jogról szóló 1894. évi XXXI. törvénycikk (Ht.) 95. 』 és 105. \a gyermekelhelyezésről és gyermektartásról a Ht. 103. \különélő szülő kapcsolattartásáról, az 1894. évi XXXIII. törvénycikk az állami anyakönyvekről 38. 』 és 42. \a gyermek névviseléséről.

5 A fogantatási idő fogalma magyar általános polgári törvénykönyv-tervezet első szövegének (1900) 188. \-ban, a magyar polgári törvénykönyv tervezete (1913) 92. \-ban, az 1928. évi „Magyarország Magánjogi Törvénykönyvének Törvényjavaslata” (Mtj.) 182. \-ban jelent meg és a bírói gyakorlatban, törvényi szinten nem volt szabályozva.

6 30.000/1947. I. M. sz. rendelet a házasságon kívül született gyermek jogállásáról szóló 1946. évi XXIX. törvénycikk hatálybaléptetése és a polgári törvénykezés körében való végrehajtása tárgyában 2 . \(1) bekezdése alapján.

7 1946. évi XXIX. törvénycikk indokolása, Általános Indokolás.

8 1911. évi I. törvénycikk a polgári perrendtartásról, Nyolczadik fejezet.

9 1911. évi I. törvénycikk a polgári perrendtartásról, Tizenharmadik fejezet.

10 1911. évi I. törvénycikk a polgári perrendtartásról, Kilencedik fejezet.

11 1911. évi I. törvénycikk a polgári perrendtartásról, Tizedik fejezet.
} 
szolgáltak az 1911. évi polgári perrendtartás szabályai szerint. Az alperes férfi a kereseti kérelemmel szemben ún. feslettségi kifogással élhetett, tehát akkor, ha a gyermek anyja a nemi érintkezést a szeméremérzetet sértő módon hajtotta végre vagy a kéjelgést keresetszerūen űzte, akkor a bíróság elutasította felperes gyermektartásdíj megállapítása iránti keresetét. Az állam felismerte, hogy ennek bizonyítása érdekében az alperes gyakran hamis tanúkkal kísérelte meg igazolni, hogy a nő a nemi érintkezést másik férfi jelenlétében végezte. ${ }^{12}$ Amennyiben az eljárásjogi nehézségeket mégis sikerült leküzdeni és a bíróság megállapította, hogy a felek a fogantatási időben nemileg érintkeztek, a következô probléma az volt, hogy a tartásdíj mértékét nem a gyermek indokolt szükségletei és egyéni képességei határozták meg, hanem az anyja társadalmi állása, illetve a kötelezett vagyoni és jövedelmi helyzete.

A gyermektartás időtartama - amelyet a keresőképes kor eléréséig kellett szolgáltatni komoly vitákat generált. A királyi Curia a 19. sz. végére általánosan a gyermek 12 éves koráig ítélte meg a gyermektartásdíjat, ${ }^{13}$ később a magyar általános polgári törvénykönyv tervezetének elsô ${ }^{14}$ és második ${ }^{15}$ szövege a tartás időtartamát a gyermek 16 éves koráig állapította meg, de amennyiben a gyermek súlyosabb hibáján kívül tovább is eltartásra szorult, teljeskorúsága eléréséig volt jogosult tartásra. ${ }^{16}$ A Zalaegerszegi királyi Járásbíróság az 1938 és 1946 közötti időszakban rendre a gyermek 16 éves koráig állapította meg a gyermektartásdij fizetési kötelezettséget. ${ }^{17}$

A másik két nagy vitás kérdés a felek közötti egyezség körében merült fel: elsőként az, hogy szükséges-e a gyámhatóság jóváhagyása az egyezség érvényességéhez, másodikként, hogy az egyezség később megváltoztatható-e. A törvénytelen gyermekek tartásának vonatkozásában köthettek egyezséget a szülők, azonban a bíróságok gyakorlata nem volt egységes ${ }^{18}$ a tekintetben, hogy a követelés csak a gyámhatóság jóváhagyásával érvényesíthető, vagy akár anélkül is. ${ }^{19}$ A királyi Curia arra az álláspontra helyezkedett, hogy amennyiben havi tartásdíj összegében egyeztek meg a szülők, akkor nem kellett hozzá gyámhatósági jóváhagyás, hogyha viszont egy összegben kívánta az apa teljesíteni a gyermektartásdij fizetési kötelezettséget, akkor az szükséges volt. ${ }^{20}$

A fenti kihívásokkal ellentétben, a törvényes házasságból született gyermekek családi állása rendezett volt, az apai jogállást betöltötték, így azon felül, hogy a gyermek tartása a születésétől fogva, peres vagy gyámhatósági eljárás lefolytatása nélkül kettő, és nem egy személyre hárult, valamint az apa halála után a gyermek örökségre is számot tarthatott. ${ }^{21}$

Fontos megjegyezni, hogy a jogi különbségtétel és a házasságon kívül született gyermek hátrányosabb helyzete azzal a következménnyel járt, hogy a gyermekhalandóság és a halva születés aránya a házasságon kívül született gyermekek körében magasabb volt, mint a házasságból

\footnotetext{
12 1946. évi XXIX. törvénycikk indokolása 18. \, 32. \.

13 MENYHÁRT, Atyasági kereset 377-379.

14 A magyar általános polgári törvénykönyv tervezete. Első szöveg, 350. S.

15 A magyar polgári törvénykönyv tervezete. Második szöveg, 216. \.

16 TÖRSEÖK, A törvénytelen 217-218.

17 MNL ZML VII. 10. c. 1938-1946. iratai.

${ }^{18}$ Erre az álláspontra helyezkedik Raics Lázár ügyvéd is „A törvénytelen gyermek tartása és a m. kir. Curia gyakorlata” című cikkében.

${ }^{19}$ HATTYUFFY, A kiskoru gyermek tartása 12-13.

${ }^{20}$ CSORNA, Rokonság 55.

${ }^{21}$ A házasságból és a házasságon kívül született gyermek közötti különbségtételről bővebben lásd még: KRAUSZ, A kiskorú gyermek tartásának szabályozása 84-93.
} 
születettek között, továbbá a fiatalkorú bűnelkövetôk és a prostituált nők nagy része szintén a házasságon kívül született gyermekek közül került ki. Az újjáépülő állam felismerte, hogy a népességszám növelése és a népesség védelme érdekében olyan jogi rendezésre van szükség, amely előfutára lehet bizonyos társadalmi változásnak is. ${ }^{22}$

\section{A gyermektartásdíj törvényi szabályozása}

A gyermektartásdíj intézményét az 1946. évi XXIX. törvénycikk 26-35. SS alatt szabályozta. A törvény eltérő rendelkezése hiányában a házasságon kívül szültetett gyermekek tartására azok a szabályok irányadók, amelyek a házasságból született gyermekek tartását a házasság fennállása alatt rendezik. ${ }^{23}$ Ez a házassági jogról szóló 1894. évi XXXI. törvénycikk (Ht.) és a gyámsági és gondnoksági ügyek rendezéséről szóló 1877. évi XX. törvénycikk (Gyt.) alkalmazását jelentette. A Ht. 95. \szerint a szülők jövedelmük arányában voltak kötelesek a gyermek tartásáról gondoskodni abban az esetben, ha a gyermeksaját keresetéből vagy vagyona jövedelméből nem volt képes magát eltartani; A Gyt. 11. \-a szerint a vagyontalan kiskorúakat elsősorban az atya, ha erre magában nem képes, vele együtt az anya, ha atya nincs, vagy erre teljesen képtelen, az anya, végül a nagyszülők tartoznak eltartani és neveltetni. ${ }^{24}$

A házasságon kívül született gyermekek jogálláról szóló törvény szerint a gyermektartásdíjfizetési kötelezettség megállapítása két esetben lehetséges. Az egyik, hogyha jogerôs bírósági ítélettel ${ }^{25}$ vagy teljes hatályú atyai elismerő nyilatkozattal ${ }^{26}$ atyai jogállás keletkezik és így tartásdíj fizetésére a házasságon kívül született gyermek apját kötelezi a bíróság, míg a másik esetben, amennyiben az atyaság megállapítása nélkül, csupán tartásdíj fizetésére kötelezés történik. ${ }^{27}$

A bíróság három esetben állapította meg az apaságot: elsőként, ha a férfi az anyával a fogantatási időn belül életközösségre utaló körülmények között huzamosabb időn át együtt élt (vadházasság esete); másodikként, ha a férfi az anyával a fogantatási időben huzamosabb időn át nemi viszonyt folytatott; harmadik esetként pedig, ha a férfi az anyával a fogantatási időben nemileg érintkezett, és az összes körülmények gondos mérlegelése mellett alapos következtetést lehet vonni arra, hogy a gyermek az említett nemi érintkezésből származik. ${ }^{28}$

A törvény hatálybalépése előtt kialakult bírói gyakorlat törvényi szintre emelésével, gyakorlatilag egy kisegítő lehetőségként szabályozta a törvény az atyaság megállapítása nélküli tartásra kötelezés intézményét. Erre abban az esetben volt lehetőség, ha a bíróság tényként állapította meg, hogy az alperes a házasságon kívül született gyermek anyjával a fogantatás idejében nemileg érintkezett. Ezt csak akkor nem lehetett alkalmazni, ha a körülmények szerint nyilvánvalóan lehetetlen, hogy a gyermek az említett nemi érintkezésből származik, vagy a gyermek anyja a kéjelgést a fogantatás idejében keresetszerűen űzte. ${ }^{29}$

\footnotetext{
22 1946. évi XXIX. törvénycikk indokolása, Általános indokolás.

23 1946. évi XXIX.tc. 26. \(1).

${ }^{24}$ KRAUSZ, A törvényes születésű kiskorú gyermek 29.

25 1946. évi XXIX. tc. 17. \-18. \$.

26 1946. évi XXIX. tc. 10. \$.

27 1946. évi XXIX. tc. 32.-35. \$S.

28 1946. évi XXIX. tc. tc. 17. \$.

29 1946. évi XXIX. tc. tc. 32. \$.
} 
A feslettségi kifogás körét tehát a törvény arra az esetre korlátozta, amikor a gyermek anyja a kéjelgést a fogantatás idejében keresetszerűen űzte. Nem tartotta fenn azt a kialakult gyakorlatot, amely szerint a gyermek - az anyja ,feslett” élete okából - akkor sem követelhet tartást, ha anyja a nemi érintkezést a fogantatás idejében a szeméremérzet teljes hiányára valló módon űzte. Az indokolásban kifejti a jogalkotó, hogy abból ugyanis, hogy az alperesként perbevont férfi a nemi érintkezésnek a szeméremérzetet sértő módon való végrehajtását bizonyítani tudja, nem lehet megnyugvással arra következtetni, hogy a nő válogatás nélkül érintkezett bárkivel, tehát olyan nagyszámú férfival, hogy ezek közül egyetlen, általa kiválasztott férfinak tartásra kötelezése a jogérzetet sértené. Ha azonban a gyermek anyja a fogantatás idejében a kéjelgést keresetszerūen űzte, akkor az említett következtetést le lehet vonni, ezért az indokolás szerint igazságtalan lenne, ha valaki pusztán azon az alapon, hogy az ilyen nővel nemileg érintkezett, tartásra lenne kötelezhető. ${ }^{30}$

Az apaság megállapítása nélküli tartásra kötelezés törvényi szabályozása mögött az a jogalkotói szándék húzódott, hogy az apaság megállapítása iránti perben előfordulhat, hogy az eset összes körülményeinek mérlegelése alapján a bíróság nem tud alapos következtetést levonni arra nézve, hogy a gyermek az említett nemi érintkezésből származik, ezért az atyaság megállapítására irányuló keresetet elutasítja. Előfordulhat az is, hogy az atyasági kereset megindítására jogosultak éppen azért, mert a pertől eredményt nem várhatnak, a keresetet meg sem indítják. Mivel ezelőtt a szokásjogi szabályok és a bírói gyakorlat szerint a tartásdíj megítélésének nem volt előfeltétele annak megállapítása, hogy a gyermek a tartás fizetésére kötelezett férfitól származik, elegendő volt azt valószínûsítenie a felperesnek, hogy a fogantatás idejében az anya és a kötelezett között nemi érintkezés történt. A házasságon kívül született gyermek jogállását rendező törvénynek viszont nem lehet a célja az, hogy a házasságon kívül született gyermekek egy részét rosszabb helyzetbe juttassa, megfossza őket a tartásdíj jogától, és ezért a korábbi szokásjogi szabályt elfogadta. Ettől eltekintve az állam azt is felismerte, hogy e szokásjogi szabály fenntartása nélkül számos gyermek eltartása az államra hárulna, és a jogalkotó álláspontja szerint az állam ezt a terhet a korabeli viszonyok között nem vállalhatta magára. ${ }^{31}$

A két leglényegesebb rendelkezés az volt, hogy egyrészt a házasságon kívül született gyermek tartásának mértéke is az atyja társadalmi állásához, valamint a tartásra kötelezett vagyoni és kereseti viszonyaihoz igazodott, másrészt a házasságon kívül született gyermeknek is joga volt arra, hogy a tehetségének, hajlamainak, szorgalmának, esetleges vagyonának, valamint a tartásra kötelezett vagyoni és kereseti viszonyainak megfelelő, önálló keresetre képesítő tanításban részesüljön. ${ }^{32}$

Ennek a jelentősége a gyermektartásdíj mértének és a szolgáltatás időtartamának meghatározása tekintetében mutatkozik meg, ugyanis lehetôséget nyújtott arra, hogy a jobb képességekkel rendelkező házasságon kívül született gyermekek magasabb iskolai képesítést kaphassanak, amennyiben a kötelezett teljesítôképes, tehát abban az esetben is tartásra jogosult

\footnotetext{
30 1946. évi XXIX. törvénycikk indokolása 32. \$.

31 1946. évi XXIX. törvénycikk indokolása 32. \$.

32 1946. évi XXIX. tc. 26. \(2).
} 
legyen, ha a nagykorú gyermek (20. életévet betöltött személy), aki fóiskolai tanulmányokat folytat, a keresőképes életkort csak ennek befejezése után éri el. ${ }^{33}$

A tartás módját akként rendezi a törvény, hogy a házasságon kívül született gyermeknek a tartást az apa - amennyiben a gyermek anyjával közös háztartásban él, vagy a gyermek az ő gondozása alatt áll - természetben köteles szolgáltatni, Ez akkor is lehetséges, ha ebbe az anya vagy a törvényes képviselő beleegyezik. Ezen kívül az apa a tartást hónaponként elôre pénzbeli járadékban köteles szolgáltatni. ${ }^{34}$

A szülők közötti egyezségkötés tárgykörében a jogalkotó előírta, hogy a házasságon kívül született gyermek és az atya közt a jövőben teljesítendő tartásra vagy annak megváltására nézve létrejött megegyezéshez a gyámhatóság jóváhagyása szükséges. Az egyezséget pedig meg lehet változtatni abban az esetben, hogyha a tartásra irányadó viszonyok utóbb lényegesen megváltoztak, vagy ha az egyezségbe foglalt tartásdíj mértéke számbavehetően csekélyebb, mint amennyi a törvény szerint járna. ${ }^{35}$

A jövőbeli tartásról való ingyenes lemondás a törvény szerint semmis jogi aktus. Más esetben, hogyha a jogosult quasi ellenérték fejében mond le a tartásról, vagyis amikor az atya a visszatérő időközökben nyújtandó tartást hosszabb időre előre kiszolgáltatja, de utóbb a gyermek ismét eltartásra szorul, akkor az atya a tartás újraszolgáltatása alól legfeljebb hat hónapra mentesül. ${ }^{36}$ Tehát a tartásról lemondani nem lehet.

A tartás jogosultja a házasságon kívül született gyermek. Amennyiben azonban a házasságon kívül született gyermeket az atyja helyett az anyja vagy eltartásra köteles más rokona vagy gyermekvédő intézet tartja el, annyiban a gyermek eltartási követelése reájuk száll át törvényes engedményként, amely szintén a bírói gyakorlatot emelte törvényi szintre. ${ }^{37}$

A törvény fenntartotta az 3982/1916. M. E. számú rendeletben foglalt szabályokat, miszerint az apa köteles megtéríteni az anyának a szüléssel járó költséget, valamint az atya vagyoni és kereseti viszonyaihoz mérve azon a költséget, amibe a szülés előtt két héten és a szülés után négy héten át az anya eltartása került, valamint, ha az anyának a terhesség és a szülés következtében még egyéb elkerülhetetlenül szükséges kiadása volt, a méltányosság szerint ezt a költséget is. Ezen költségeknek a rendszerint szükséges összegét az anya annak kimutatása nélkül követelhette, hogy valóban mennyit költött. Ezen igényeket a gyermek születésétől számított három éven belül követelhette az anya, és ezek megillették őt akkor is, ha a gyermek halva született, vagy ha az atya a gyermek születése előtt elhunyt. ${ }^{38}$

Törvényi szinten lett szabályozva az is, hogy a bíróság az anya kérelmére ideiglenes hatályú határozattal azt, akinek az atyasága valószínű, már a gyermek megszületése előtt arra kötelezheti, hogy a gyermek első háromhavi eltartásának költségét a szülés után előleges havi részletekben a gyermek részére, az anyának járó költséget pedig a rendszerint szükséges összegben azonnal a szülés után az anya részére fizesse meg, és a fizetendő összegeket megfelelő idővel a szülés előtt helyezze

\footnotetext{
33 1946. évi XXIX. törvénycikk indokolása 26. S.

34 1946. évi XXIX. tc. 27. \$.

35 1946. évi XXIX. tc. 28. \(1)-(2).

36 1946. évi XXIX. tc. 28. \ (1), (3); 1946. évi XXIX. törvénycikk indokolása 28. \.

37 1946. évi XXIX. tc. 29. \; 1946. évi XXIX. törvénycikk indokolása 29. 』.

38 1946. évi XXIX. tc. 30. \(1)-(3); 1946. évi XXIX. törvénycikk indokolása 30. \.
} 
bírói letétbe. A kérelmezőnek nem kell valószínűsítenie azt a tényt, hogy a követelés veszélyeztetve van, vagy hogy az anya a költségek előlegezésére rászorul, és nem mentesül a kötelezettség alól a kötelezett arra hivatkozással, hogy a szülés költségét nem az anya, hanem más fogja fedezni. A bíróság sürgős szükség esetén ideiglenes határozattal azt is elrendelhette, hogy a kötelezett az anya részére a szülés előtti két hétre járó anyatartás költségét megfelelő idővel a szülés előtt fizesse meg. Amennyiben a gyermek születését születési anyakönyvi kivonattal bizonyítják, úgy a letétbe helyezett összegből a bíróság kiutalványozza a gyermek tartásdíját előre esedékesen, havi részletekben a gyermek részére, amennyiben a gyermeket az anya tartja magánál, annak kezéhez, ellenkező esetben a gyermek törvényes képviselőjének kezéhez, ha pedig a gyermek állami menedékhelyen vagy más gyermekvédő intézetben van elhelyezve, az intézet pénztárának. A terhesség és a szülés költségét, valamint az anya eltartási költségét pedig egy összegben az anya részére utalványozza ki. Ha a gyermek halva születik vagy meghal, a bíróság a letett gyermektartásdijat vagy felszabadult részét a letevőnek visszautalványozza. ${ }^{39}$

Az atyaság megállapítása nélkül tartásra kötelezés esetében is a fent említett jogszabályi elő́rásokat kellett alkalmazni, tekintettel azonban arra, hogy ebben az esetben a házasságon kívül született gyermek és a kötelezett nem kerülnek jogilag rokoni kapcsolatba, további rendelkezések is vonatkoznak erre a jogviszonyra. A törvény kimondja, hogy a házasságon kívül született gyermek tartási igénye a tartásra kötelezett halálával nem szűnik meg, ez átszáll a kötelezett örököseire akkor is, ha a gyermek a tartásra kötelezett halála után született. A tartásdíj azonban csak olyan mértékủ járadék lehet, amilyennek szolgáltatására a tartásra kötelezettet a házasságból származó gyermekei, házastársa és volt házastársa részére járó tartás számbavételével a hagyaték alapján kötelezni lehetne. ${ }^{40}$ Ennek indokaként a jogalkotó azt jelölte meg, hogy az atya halála után az ő legközelebbi családtagjai is a családfő keresetének hiányában csak a hagyatékra vannak utalva, tehát nem volna méltányos a házasságon kívüli gyermek tartásdíját a változott helyzet ellenére változatlan összegben meghagyni. ${ }^{41}$ A törvény az örökösök érdekeinek védelme érdekében lehetőséget ad arra is, hogy a tartásra kötelezett örököse megválthassa a házasságon kívül született gyermekkel szemben fennálló kötelezettségét oly összeggel, amely a gyermeknek, ha házasságból született volna, atyja hagyatékából kötelesrészül járna, ha több ilyen gyermek van, a megváltás összegét úgy kell kiszámítani, mintha mindegyikük házasságból született volna. ${ }^{42}$

A jogosult, vagyis a házasságon kívül született gyermek halála esetén a tartásra kötelezettel, vagy annak örököseivel szemben csak a házasságon kívül született gyermek halálát megelôző időtartamra szóló tartás szolgáltatása és kártérítés iránti igény ${ }^{43}$ támasztható. Az eltartásra jogosult gyermek temetésének költsége pedig ebben az esetben annyiban terheli a tartásra kötelezettet, amennyiben a költség a házasságon kívül született gyermek hagyatékából ki nem telik. ${ }^{44}$

\footnotetext{
39 1946. évi XXIX. tc. 31. 』(1)-(4).

40 1946. évi XXIX. tc. 33. S.

41 1946. évi XXIX. törvénycikk indokolása 33. \ (1).

42 1946. évi XXIX. tc. 33. S (2).

43 1946. évi XXIX. tc. 30. \(4) bekezdése szerint, ha az atya az anyát házassági ígérettel vagy függő helyzetének kihasználásával csábította el, az anya a szüléssel kapcsolatban felmerült követelésén felül a tiltott cselekményekre vonatkozó szabályok szerint kártérítést is követelhet.

44 1946. évi XXIX. tc. 34. S.
} 
A törvény fenntartotta még azt a szokásjogi rendelkezést is, hogy a tartásra kötelezett tartozásáért a szülője kezes módjára felel, amennyiben a tartásra kötelezett egészben vagy túlnyomórészben szülőjének gazdaságában, üzletében vagy más kereső foglalkozásában fejti ki tevékenységét és ezért megfelelő díjazásban nem részesül. A szülő kötelezettsége akkor is fennáll, ha a tartásra kötelezett tevékenységében önhibáján kívül ideiglenesen akadályozva van. ${ }^{45}$

\section{A Zalaegerszegi Járásbíróság gyakorlata}

A kutatás során átvizsgáltam a Magyar Nemzeti Levéltár Zala Megyei Levéltárának iratanyagai közül a Zalaegerszegi Járásbíróság polgári peres iratait a törvény hatálybalépését követő időszakban, 1950-el bezárólag. A továbbiakban bemutatok - példálózó jelleggel - néhány peres ügyet a bírói gyakorlatból, így képet kaphatunk az 1946. évi XXIX. törvénycikk alkalmazásáról.

A törvény 29. \-a szerint, ha a gyermeket gyermekvédő intézet tartja el, akkor a követelés az intézetre száll át, ilyen eset a gyakorlatban is fellelhető volt. Az 1948. november 4. napján érkezett keresetlevélben az államkincstár volt a felperes, az alperes pedig B. István, a gyermek apja. A keresetlevélben a felperes előadta, hogy az alperes és Cs. Gizella kapcsolatából 1943. május 24. napján gyermek született, akit a születésétől kezdődően a szombathelyi állami gyermekmenhely tart el és gondoz. A gyermek eltartásával kapcsolatban a 80.558/1947/III.-1. N. M. sz. rendeletben megállapított költségek, valamint havi 25 forint ruházati költség merült fel, amelynek megtérítésére az alperes nem hajlandó. Kérte a bíróságot, hogy kötelezze az alperest arra, hogy fizessen meg a gyermek után 1946. augusztus 1-ig egy összegben 1000 forintot, 1946. augusztus 1-tôl 1947. november 1-ig havi 45 forintot, 1947. november 1-től a Népjóléti Minisztérium 101.174/1947. I. M. számú rendelete alapján a hetedik életévének betöltéséig havi 53 forintot, a tizenkettedig életév betöltéséig havi 47 forintot és végül a tizenhatodik életév betöltéséig havi 43 forintot gondozási és ruházati költségként, valamint fizesse meg a felmerülő perköltséget.

Az elsőfokú bíróság elutasította a felperes keresetét, mivel a lefolytatott bizonyítási eljárásban arra az álláspontra helyezkedett, hogy bizonyíték hiányában nem állapítható meg az, hogy a gyermek anyja és az alperes a vélelmezett fogamzási időben nemileg érintkeztek volna.

A törvényszék mint másodfokú bíróság a járásbíróság itéletét megváltoztatta és kötelezte az alperest arra, hogy 1948. május 1. napjától kezdődően minden hónap első napján mindaddig, amíg a kiskorú állami gyermekmenhely gondozásában áll, de legkésőbb 16. életévének betöltéséig havi 42 forint tőkét fizessen meg. A hátralékos díjtartozás megfizetésére három havi részletfizetést engedélyezett és perköltségekben marasztalta.

Az indokolásában kifejtette a bíróság, hogy a felvett bizonyítási eljárás alapján megállapításra került, hogy a fogantatási időben az alperes és a gyermek anyja nemileg érintkeztek, illetve, hogy az alperesnek havi 80-100 forint jövedelme van, háza és 800 négyszögöl kertje. A gondozási és ruházati díjakat azonban a kereset beadásától számított hat hónapra visszamenőleg állapította meg, mert nem volt olyan indok, ami az ettől eltérő, hosszabb időre történő megállapítást indokolná. ${ }^{46}$

\footnotetext{
45 1946. évi XXIX. tc. 35. §.

${ }^{46}$ MNL ZML VII.10.c. P.1818/1848.
} 
A törvény 31. \-a alkalmazására, vagyis az előzetes tartásdíj megállapítására példaként említhető a Zalaegerszegi Járásbíróság előtt P.882/1947. számon folyt ügy. A keresetlevél 1947. június 20. napján érkezett a bíróságra. A felperes $F$. Anna, 26 éves hajadon, vagyontalan napszámos jogi képviselője útján előadta, hogy 1946. október 10. napjától 1947. március 28. napjáig közös háztartásban élt az alperessel, Cs. Józseffel Zalaegerszegen, és a kereset beadásakor a zalaegerszegi közkórház szülészfőorvosának igazolása szerint a terhesség ötödik hónapjában van. Előadta, hogy amikor erról az alperes tudomást szerzett, elkergette őt a közös lakásukból és a születendő gyermekről gondoskodni, valamint a szülési költségeket megelőlegezni nem hajlandó. Az 1946. évi XXIX. évi tc. 31. \(1) bekezdése alapján kérte, hogy kötelezze ôt a bíróság három havi tartásdij fejében 120 forint, hat heti munkamulasztás, szülési és kelengyebeszerzési költség fejében 600 forint 1947. augusztus 15. napjáig történő bírói letétbe helyezésére és perköltség fizetésére.

A bíróság a felperes részére bélyeg- és illetékmentességgel járó szegénységi jogot engedélyezett. Az 1947. augusztus 23. napján tartott tárgyaláson a felek együttesen adták elő, hogy 1946. októbertól 1947. márciusig együtt éltek, illetve, hogy az alperes anyja is velük élt egy lakásban. Az alperes előadta, hogy azt nem tudja bizonyítani, hogy a felperes feslett életmódot folytatott volna, valamint, hogy vagyontalan napszámos, a 75 éves édesanyját is támogatnia kell, mert olyan kevés a nyugdíja, ugyanakkor hivatkozott a szegénységi bizonyítványára. Annak bizonyítására, hogy az anyja tartásához hozzájárul - jogi képviselője útján - tanúbizonyítást indítványozott és előadta, hogy az anyjának 119 forint a nyugdíja. A felperes ezeket nem tagadta, ezért a bíróság a további bizonyítást mellőzte és végzéssel kötelezte az alperest arra, hogy helyezzen bírói letétbe 1947. szeptember 15. napjáig a felperes részére a születendő gyermeke három havi tartására 90 forintot, valamint munkamulasztás, kelengyebeszerzési és szülési költségekre 300 forintot, valamint 60 forint perköltséget.

A 3. számú végzés indokaként kifejtette a bíróság, hogy az alperes beismerte, hogy a kérelmezővel 1946. októbertől 1947. márciusig közös háztartásban élt, ezért valószínűsítve van, hogy a kérelmező születendő gyermeke az alperestől származik, ezért őt az 1946. évi XXIX. törvénycikk 31. \-a érelmében a kereseti viszonyainak megfelelő tartásdíj összeg letétbe helyezésére kötelezte. ${ }^{47}$ Ezen ügyben nem maradt fenn a kiutalásról rendelkező okirat.

Egy másik ügyben, nevezetesen a Zalaegerszeg Járásbíróság P.918/1947. számú eljárásban L. Teréz kérelmező az 1947. június 27. napján érkezett kérvényében előadta, hogy N. Lajos kérelmezett hivatásos repülőőrmester, jelenleg földműves zalalövői lakossal házasságon kívüli szerelmi viszonyt folytatott, tőle teherbe esett és a gyermeket 1947. október hónapra várja. Tekintettel arra, hogy vagyontalan, jövedelemmel nem rendelkezik, és nem tud gondoskodni a gyermeke tartásáról, kérte, hogy a bíróság kötelezze a kérelmezettet arra, hogy helyezzen letétbe a megszületendő gyermeke három havi tartása fejében havi 80 forint számításával mindösszesen 240 forintot, szülési, gyermekágyi és gyermekkelengye költség fejében pedig 800 forintot és viselje az eljárási költségeket. Az összegeket megállapító végzés nem maradt fenn, azonban a 4. számú jegyzőkönyv tanúsága szerint 1947. október 28. napján megjelentek a felek a tárgyaláson, ahol a kérelmező előadta a 3. számú kérvénye tartalmát, kérelmezett pedig beleegyezését adta, hogy a bíróság által 2. szám alatti végzéssel megállapított és a kérelmező jogi képviselője részére kifizetett összeget a kérelmező kezéhez kifizethessék, illetve vállalta a 40 forint ügyvédi költség megfizetését.

\footnotetext{
${ }^{47}$ MNL ZML VII.10.c. P.882/1947.
} 
Ez alapján a bíróság a végzésében felhívta a kérelmező jogi képviselőjét, hogy nála letétbe helyezett összeget fizesse ki a kérelmezőnek és kötelezte a kérelmezettet 40 forint költség megfizetésére a kérelmező jogi képviselője részére. ${ }^{48}$

A törvény 30. és 32. \-ának rendelkezéseire, vagyis a gyermektartásdíj és járulékai megállapítására példaként hozható fel az a P.1277/1947. számú ügy, amelyben 1947. augusztus 29. napján érkezett keresetlevél. A felperes K. Vilma háztartásbeli napszámosnő, az alperes F. Sándor földmúves. A felperes kereseti kérelmében előadta, hogy az alperessel szerelmi viszonyt folytatott, aki ôt házassági ígérettel nemi kapcsolatra bírta és ennek következtében 1944. október 13. napján gyermeke született. Az alperes a gyermekről nem gondoskodik és így a felperesnek egyedül kell gondoznia a gyermeket, a szüleire van utalva. Az alperes birtokos gazda, akinek módjában áll a gyermek eltartása, az alperes anyja és lánytestvére - aki a gyermek keresztanyja - azt szeretnék, hogyha az alperes elvenné feleségül a felperest, azonban az alperes vagyonosabb lányt akar feleségül venni. A felperes előadta, hogy szereti az alperest, jó felesége lenne és a gyermek is szép és egészséges. Azért nem indított eddig pert, mert a saját és a gyermeke jövője érdekében is arra számított, hogy az alperes feleségül veszi, valamint az alperes anyja és testvére is azt kérték, hogy legyen türelemmel. Kereseti kérelmében kérte a bíróságot, hogy kötelezze az alperest a gyermek születésétől kezdődően havi 50 forint gyermektartásdij megfizetésére annak 16 éves koráig, 360 forint anyatartási, 200 forint szülési és kelengyeköltség megfizetésére.

Ezen ügyben a járásbíróság az 1947. szeptember 24. napján meghozott ítéletében arra kötelezte az alperest, hogy a felperesnek az 1944. október 13. napján született gyermeke tartása fejében 1947. február 28. napjától a gyermek 16. életévének betöltéséig minden hónap 1. napján előre havi 30 forint tartásdíjat fizessen meg. Kötelezte továbbá szülési, anyatartási és gyermekkelengye költség fejében 350 forint és 100 forint perköltség 15 napon belüli megfizetésére. A kereset ezt meghaladó részét elutasította, és az itéletnek a lejárt és a per alatt lejárt részletekre nézve fellebbvitelre való tekintet nélkül végrehajthatónak nyilvánította.

Az ítélet indokolásában a bíróság kifejtette, hogy az alperes elismerte, hogy a vélelmi idő alatt a felperessel nemileg közösült, azonban azt tagadta, hogy ő volna a gyermek természetes apja és mennyiségi kifogással élt. A bíróság levezette, hogy az, aki a gyermek anyjával házasságon kívül a vélelmi idő alatt nemileg közösül a házasságon kívül született gyermek természetes apjának vélelmezendő. A természetes apa a törvénytelen gyermekét eltartani köteles, továbbá az állandó bírói gyakorlat értelmében megtéríteni az anyának mindazokat a díjakat és költségeket, amelyek a születéssel merültek fel. A tartásdíj mértékének megállapításánál a bíróság figyelembe vette, hogy az alperesnek az összes vagyona 1 hold 1000 négyszögöl, az alperesnek felesége és egy kisgyermeke van, akiknek az eltartásáról is ő köteles gondoskodni, ezért havi 30 forintban állapította meg a gyermektartásdij havi összegét, amely összeg a gyermek eltartására szükséges, azonban az alperes családjának megélhetési viszonyait nem veszélyezteti, míg a keresetnek ezt meghaladó részét, mint eltúlzott követelést elutasította. A szülési költségek fejében a bíróság 350 forintot állapított meg, mert a felpereshez hasonló társadalmi állású egyéneknél ezek a díjak körülbelül ennyit szoktak kitenni, az ezt meghaladó részt szintén elutasította. ${ }^{49}$

\footnotetext{
48 MNL ZML VII.10.c. P.918/1947.

${ }^{49}$ MNL ZML VII.10.c. P.1277/1957.
} 
A törvénycikk 35. S-ának alkalmazására példa a P.976/1947. számú ügy, amelyben gyermektartásdíj fizetésére kötelezésre az apaság megállapítása nélkül került sor, és a nagyszülők kezes módjára feleltek a tartásdijra kötelezett férfi tartozásáért. Ezen ügyben a keresetlevél 1947. július 5. napján érkezett a Zalaegerszegi Járásbíróságra, a felperes a házasságon kívül született gyermek, $V$. Mária németfalui lakos volt, akit a perben kiskorúságára tekintettel $d r$. Saalay Gyula vármegyei tiszti föügyész képviselt ügygondnokként. Az I. r. alperes $P$. Károly, a felperes vélelmezett apja, II. alperes az ő édesapja P. Ferenc, a III. r. alperes pedig az édesanyja, P. Ferencné volt. A felperes kereseti kérelmében előadta, hogy a felperes anyja és I. r. alperes 1946. június 30. és október közötti időben szerelmi viszonyt folytatott, amelyből 1947. április 24. napján gyermekük született. Az I. r. alperes nem hajlandó a gyermeket magáénak elismerni és atyaság megállapítása iránti eljárás még nincs folyamatban, ezért Zala vármegye árvaszéke az anya kérelmére határozatával ügygondokot rendelt ki és arra utasította, hogy az 1946. évi XXIX. tv. 32. \alapján indítson eljárást. Kereseti kérelmében a gyermek születésétől kezdve annak 16. életévének betöltéséig havi 40 Ft tartásdíj megfizetését kérte előre esedékesen minden hónapban. Előadta továbbá, hogy az I. r. alperes a II. és III. r. alperesekkel él közös háztartásban és azok gazdaságában tevékenykedik anélkül, hogy díjazásban részesülne, ezért egyetemlegesen őket is kérte gyermektartásdíj fizetésére kötelezni.

A 14. szám alatt 1948. május 20. napján meghozott ítéletben a bíróság kötelezte I. r. alperest arra, hogy a felperes születésétől kezdődően addig, amíg a 16. életévét be nem töltötte fizessen meg havonta 40 forint gyermektartásdíjat és 300 forint perköltséget. Kimondta, hogy II. r. és III. r. alperesek ezen tartozásokért kezesként felelnek. A tartásdijfizetési hátralék és a perköltség 15 napon belül egy összegben fizetendő, a jövőben lejáró tartásdíj részletek pedig minden hónap 24. napján, illetve, hogy az ítélet fellebbezésre tekintet nélkül végrehajtható.

A bíróság az indokolásában megállapította, hogy a felperes vélelmezett fogamzási ideje 1946. június 9. és 1946. október 7. közötti időre tehető. Az alperes tagadta azt, hogy a felperes anyjával ez idő alatt nemileg érintkezett, azonban az alperes ezen állításának igazolására a perben bizonyíték nem merült fel. Az eskü alatti kihallgatása során azt elismerte, hogy ismerte a felperes anyját és 1946 nyarán többször hívta ôt a szülei gazdaságába dolgozni, valamint, hogy a mulatságok idején meg szokta táncoltatni. Gy. Istvánné érdektelen tanú elmondta, hogy az 1946. augusztus 18. napján tartott búcsú napján este 9 óra körül látta a felperes anyját és I. r. alperest összeölelkezve, illetve $A$. József érdektelen tanú 1946 októberében a szüretkor látta őket a felperes anyja szüleinek a háza végében beszélgetni. A bíróság ezek alapján a felperes anyját bocsátotta esküre és tényként állapította meg, hogy a vélelmezett fogamzási időben szerelmi viszont folytatott az I. r. alperessel. Figyelembe vette továbbá bizonyítékként a vércsoportvizsgálat eredményét, amely szerint a felperes származhat az I. r. alperestől, ezért kötelezte őt gyermektartásdíj fizetésére. A bíróság a tartásdíj mértékének meghatározásakor I. r. alperes társadalmi állását, vagyoni és jövedelmi viszonyait figyelembe véve megállapította, hogy a havi 40 forint nem eltúlzott.

A II. és III. r. alperesek azzal védekeztek, hogy az I. r. alperes munkájára a gazdaságukban nincs szükség, azt a tényt, hogy az I. r. alperes a gazdaságukban tevékenykedik és ezért megfelelő díjazásban nem részesül, nem tagadták. Az alperesek védekezésével szemben a bíróság azonban abból a ténykörülményből, hogy II. r. alperes 78 éves, III. r. alperes 65 éves és az együttes vagyonuk a 6000 ölt is meghaladja, azt a következtetést vonta le, hogy a fiuk munkájára a gazdaságukban szükség van. Mellőzte a bíróság I. r. alperesnek a vércsoportvizsgálat kiterjesztésére vonatkozó 
bizonyítási indítványát, mert addigra már megérkezett a vizsgálat eredménye I. r. alperes vonatkozásában. Mellőzte Gy. Istvánné újbóli tanúkihallgatására vonatkozó és $M$. Ferenc meghallgatására vonatkozó indítványát is, amellyel azt kívánta bizonyítani, hogy Á. József olyan nyilatkozatot tett $M$. Ferenc előtt, hogy neki is volt szerelmi viszonya a felperes anyjával és azért tett vallomást az I. r. alperes ellen, hogy meghálálja, hogy őt nem fogta perbe. A bíróság megítélése szerint, még ha a tanú valóban tett is ilyen nyilatkozatokat peren kívül egy magánbeszélgetés során, annak nem lenne olyan jelentősége, ami megerôtlenítené a felperes anyjának a bíróság előtt eskü alatt tett vallomását, ezért a bíróság ezt is mellőzte mint feleslegeset. A felperes arra vonatkozóan terjesztett elő bizonyítási indítványt, hogy a felperes anyját és I. r. alperest 1946 húsvét és pünkösd között látták beszélgetni a késő esti órákban. A bíróság ezt is elvetette, mivel a perben felmerült többi bizonyíték alapján a kellően tisztázottnak látta azt a körülményt, hogy az I. r. alperes milyen kapcsolatban állt a felperes anyjával.

Az alperesek fellebbezéssel éltek az ítélet ellen, így a Zalaegerszegi Törvényszék Pf.2403/1948/18. számú végítéletével 1948. szeptember 11. napján az elsőfokú bíróság ítéletét helybenhagyta és 86 forint perköltség megfizetésére kötelezte az alpereseket. Az indokolásban a bíróság kifejtette, hogy a Te. 33. \2. fordulata ${ }^{50}$ alapján az ítéletet helyes indokainál fogva hagyta helyben, mivel az anya eskü alatti és esküvel megerősített vallomása és a vérvizsgálat eredménye miatt közömbös, hogy az anya a kritikus időben más férfival folytatott-e szerelmi viszonyt vagy sem. Emellett, mivel a fogamzási időben fennforgott nemi viszonyra alapos következtetést engedő tanúvallomásokra és az anya esküvel megerősített vallomására tekintettel még annak valósága esetén sem lenne semmi jelentősége, hogy az anya peren kívül miként nyilatkozott, ezért a további bizonyításfelvételt a törvényszék mellőzte. ${ }^{51}$

\section{5. Összegzés}

A házasságon kívül született gyermek jogállásáról szóló 1946. évi XXIX. törvény nagy jelentőségű volt a tekintetben, hogy megszüntette a jogi különbségtételt a törvényes házasságból és azon kívül született gyermekek között és törvényi szinten, átfogóan rendelkezett fontos családjogi intézményekről.

A törvényt többen ellenezték, ${ }^{52}$ többen üdvözölték. ${ }^{53} \mathrm{Az}$ ellenzők az erkölcstelenség terjedését látták benne és a házasság intézményének elértéktelenedését. Szladits szerint a törvény jogszerkezeti szempontból tökéletes munka, az aggályait viszont ő is kifejezte abban a körben, hogy a család védelme érdekével szemben álló lehet, hogy a házas férfinek a másik nőtől született gyermeke is a rokona, így örököse lesz. Álláspontja szerint a házasságból és azon kívül született gyermekek között mindig különbség lesz, az előítéleteket szociális neveléssel lehetne ellensúlyozni és magasabb állami szerepvállalással, nevezetesen - szovjet példára - nevelési támogatással. ${ }^{54}$

\footnotetext{
${ }^{50}$ A Pp. 507. \-át a következő rendelkezés egészíti ki: egyébként, ha a fellebbezési bíróság az elsőbíróság ítéletében foglalt tényállást és indokokat helyeseknek találja, ítéletének indokolásául arra szorítkozhatik, hogy az elsőbíróság itéletét indokainál fogva helybenhagyja.

51 MNL ZML VII.10.c. P.976/1947.

52 TELLER, A házasságon kívül született gyermek 237-238.

${ }^{53}$ BACSÓ, Erkölcsi vita egy törvényjavaslat körül 319-323.

${ }^{54}$ SZLADITS, A házasságon kívül született gyermek jogállásáról szóló törvényjavaslat 210-212.
} 
Niæsalovsæky Endre szintén elismerte azt, hogy számos szempontból előrelépést jelent a törvény, hisz például csökkenhet a gyermekhalandóság, viszont aggályát fejezte ki, hogy a tartás mértékének az apa vagyoni viszonyához igazítása „női fondorlatra” ad lehetőséget, illetve - Szladitshoz hasonlóan - helyesebbnek tartotta volna, hogyha a házasságtörésből származó gyermekek csak tartási igényt formálhatnának. ${ }^{55}$

A törvényben foglalt gyermektartásdíjra vonatkozó jogszabályi rendelkezések nagyrészt a korabeli bírói gyakorlatot követték, a jogalkotó által pontot téve néhány szakmai vita végére. A megvizsgált peres iratok között éppen ezért nem érzékelhetünk éles váltást a jogszabály kihirdetése vagy hatálybalépése utáni időszakban a gyermektartásdij megállapítása és felemelése iránt indított perek vonatkozásában, mert ugyanazon elvek alapján döntött a bíróság, mint azelőtt. A keresetlevélben a gyermek születésétől kezdődően kérte a felperes a gyermektartásdíj megállapítását annak 16. éves koráig, valamint igényelte a szülési, hat heti anyatartási és gyermekkelengye költség megfizetését az akkori szokásos mértékben. Azt kellett bizonyítania a felperesi oldalnak, hogy a házasságon kívül született gyermek anyja a fogantatás idejében az alperessel nemileg érintkezett, főleg tanúbizonyítás és okirati bizonyítás alapján, azonban előtérbe kerültek a vérvizsgálatok eredményei is. Ezután a bíróság megvizsgálta a felek jövedelmi viszonyait és megállapította a gyermektartásdij mértékét.

Az ilyen tárgyú perekben tehát nem érzékelhető számottevően a házasságon kívül született gyermek jogállásáról szóló törvény gyakorlati hatása, aminek az indokát abban találom, hogy mivel a törvény a korszak gyakorlatát emelte törvényi szintre, ezért inkább fordítva, a bírói gyakorlat hatása érződik a jogszabályban.

\section{Felhasznált irodalom és források}

Az Igazságügyminisztérium kebelében szervezett állandó bizottság szerkesztő tagjai: A magyar általános polgári törvénykönyv tervezete. Első szöveg. Második kiadás. Budapest 1900

Az Igazságügyminisztériumban szervezett állandó bizottság: A magyar polgári törvénykönyv tervezete. Második szöveg. Budapest 1913

BACSÓ Ferenc: Erkölcsi vita egy törvényjavaslat körül. Jogtudományi Közlöny 1946/23-24. sz. 319-323.

HATTYUFFY Dezső: A kiskoru gyermek tartása és a m. kir. Curia gyakorlata. Jogtudományi Közlöny 1899/2. sz. $12-13$.

KÖTE Sándor - RAVASZ János (szerk.): Dokumentumok a magyar nevelés történetéből 1849-1919. Budapest 1979

KRAUSz Bernadett: A kiskorú gyermek tartásának szabályozása a polgári korban Magyarországon a hatályos szabályozás tükrében. Díké 2019/1. sz. 83-100.

KRAUSz Bernadett: A törvényes születésű kiskorú gyermek tartása a házasság fennállása alatt és felbomlása után 1938 és 1945 között Magyarországon. Díké 2018/2. sz. 16-32.

Magyar Nemzeti Levéltár Zala Megyei Levéltára VII. 10. c. Zalaegerszegi Járásbíróság iratai, Polgári peres és peren kívüli iratok 1945-1950.

Magyarország Magánjogi Törvénykönyve, a m. kir. igazságügyminiszter által 1928. március 1-én az Országgyülés elé terjesztett törvényjavaslat. Budapest 1928

MENYHÁRTH Gáspár: Atyasági kereset s a törvénytelen gyermek tartása. Jogtudományi Közlöny 1893/48. sz. $377-379$.

MIKOS Ferenc - ZAJTAY Imre - SÁRFFY Andor (szerk.): A polgári eljárásjog legujabb szabályai. Második átdogozott és bővített kiadás. Budapest 1947

\footnotetext{
${ }^{55}$ NizsALOVSZKY, A házasságon kívüli gyermek jogállása és az erkölcs 51-53.
} 
NIZSALOVSZKY Endre: A házasságon kívüli gyermek jogállása és az erkölcs. Jogtudományi Közlöny 1947/3-4. sz. $51-53$.

RAICS Lázár: A törvénytelen gyermek tartása és a m. kir. Curia gyakorlata. Jogtudományi Közlöny 1900/35. sz. 241244.

SZLADITS Károly (szerk.): Magyar magánjog II. Budapest 1940.

SZLADITS Károly: A házasságon kívül született gyermek jogállásáról szóló törvényjavaslat. Jogtudományi Közlöny 1946/15-16. sz. 209-212.

TELLER Miksa: A házasságon kívül született gyermek mostohaanyjának jogi helyzete. Jogtudományi Közlöny 1946/17-18. sz. 237-238.

TÖRSEÖK Károly: A törvénytelen gyermek tartási kötelessége a magyar polgári törvénykönyv tervezete szerint. Jogtudományi Közlöny 1913/25. sz. 217-218. 